\title{
Exploring Agency Theory Implications With Franchising
}

Dean R. Manna, (Email: manna@rmu.edu), Robert Morris University

Alan D. Smith, (Email: smitha@rmu.edu), Robert Morris University

David P. Synowka, (Email: synowka@rmu.edu), Robert Morris University

\begin{abstract}
The franchiser-franchisee relationship (FFR) can be examined from two theoretical perspectives, Agency Theory and Exchange Theory. Strategic management of demands that the leadership makes decisions on what the company should do and what the company should not do. This type of decision-making is called making trade-offs and has much to do with Agency Theory's applications to FFR. One reason that operational effectiveness is the preferred way is that it has inherently little risks during the short term. Managers would be willing to make decisions if the risks were not so high on the long term. From the Agency Theory viewpoint, dual distribution can be analyzed in a cost versus cost trade-off schema. The approach argues that both franchising and company ownership have costs associated with them. Dual distribution is considered an internal solution to the cost tradeoff. Some of the costs in question are inefficiency of client risk sharing, franchisees that are free riding and the legal costs of terminating a franchise. Under dual distribution the mix of company ownership and franchising minimizes the sum of these total costs. When looking at market demand and the impact strategic decisions may influence it several factors come into play, including point of sale service. The components include the impact of outlet level services provided to the consumer enhancing value via the shopping experience, the franchiser's level of effort to streamline the supply chain to all retail outlets, which enhances the image and reputation of the brand with the customer. Aspects of Agency Theory can be extended to include credible communication of franchise brand equity.
\end{abstract}

\section{INTRODUCTION}

\section{Franchising}

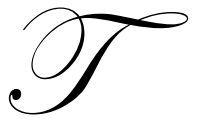

he selling of franchise contracts has become a major source of capital for business expansion in the U.S. and abroad since the 1970s (Brickley, 1991; Combs, Michael, and Castrogiovanni, 2004). In 1990 , there were an estimated 500,000 domestically franchised units accounting for over $\$ 7$ billion in total U.S. sales per year. Furthermore in 1990, American franchises employed approximately 6.9\% of total nonagricultural employees (Combs, 1994). Initially, franchising began in the restaurant, retail, and service industries (Castrogiovanni, Bennett, and Combs, 1995). However, there have been recent attempts to expand into other industries such as banking (Brickley, 1991). From a strategic standpoint, franchising is an important capital source for small businesses and initial startups attempting to expand in an ever-increasingly competitive environment.

Under this view, the company sells off locations during its stages of growth with the intention of repurchasing these units as the company matures (Combs, Michael, and Castrogiovanni, 2004). Whereas, the nontraditional view argues that franchising is not limited to small companies. There are many large companies that engage in franchising in that they own some units which are financed through public equity and debt claims while selling rights to individuals to open additional units under the corporate name. Some examples of large corporations that participate in franchising are McDonald's, Sheraton Hotels, Sears, and H\&R Block, just to name a few. 
In a typical franchise agreement, the franchisee purchases the rights to the profits from a particular unit by putting up an initial investment fee and participating in an agreement to pay ongoing sales royalties to the central franchiser. In return, the franchisee has the right to use the trademark and operating procedures of the company at that location while maintaining autonomy to hire personnel, advertise, to name a few. Ultimately, the franchiser reserves the right to monitor the quality of the product and the value of the trademark in relation to the corporate image (Brickley 1991).

\section{Strategic Benefits}

So in essence, franchise type relationships benefit the franchiser and the franchisee mutually. The corporation makes money from corporately owned locations as well as collecting royalties from independently ran units without all of the costs and hassles associated with everyday business associated with said units. The franchisee, on the other hand, benefits from the corporation by utilizing trademarks and business operations of an established, successful company.

\section{Agency Theory Perspectives}

Although the above-mentioned situation seems ideal, every business deal comes with potential risks and costs associated with it. Perhaps the theory that is most applicable to such an agreement of incomplete information and uncertainty is Agency Theory (Mathieu, 1997). Applications of Agency Theory may explain potentially beneficial ways to organize relationships in which one party (the principal) determines the work that another party (the agent) undertakes. Furthermore, Agency Theory argues that the two most common agency problems are adverse selection and moral hazard. Adverse selection pertains to the condition under which the principal cannot determine if the agent possesses the ability to do the work for which he is being paid. Moral hazard addresses the doubt that the principal incurs when considering if the agent has put forth maximum effort to fulfill his duties.

The underlying problems of adverse selection and moral hazard debate the issue of fixed wage contracts and incentive based contracts between a principal and an agent. A fixed wage contract may encourage agents to shirk on his duties since his compensation will be the same regardless of his quality of work or effort level. While a totally incentive based contract may encourage agents to act in their own interest without consideration of the agent. For example, a CEO may participate in corrupt behavior in an attempt to gain capital for himself without considering the effect that such behaviors would have on the company's overall profitably or trust among the shareholders. Therefore, applications of Agency Theory (Mathieu, 1997) suggest that some form of ownership reduces the incentives for agents' adverse selection and moral hazard since it makes their compensation dependent on their performance/actions.

Perhaps this is why franchising is so effective. The franchisee has to assume accountability and responsibility for his actions within his franchised unit. If the franchisee acts inappropriately or does not involve him in operations, his personal compensation will suffer not to mention the possible retributions that the corporation may impose on the franchise.

\section{Potential Problems and Solutions to Franchising}

Measuring a franchise's performance is one of the key factors for success from the corporation's (principal's) standpoint. The corporation must ensure that all members of the system work to develop and maintain its brand name/image without attempting to take a "free ride" off of the efforts of other franchisees/corporation that work hard to develop and maintain the brand name/image. If each franchisee (agent) does not work to uphold the principals and beliefs set forth by the corporation, the corporation's reputation and business could start to deteriorate. For example, a customer visiting an unfriendly and dirty franchised McDonald's would probably not visit another McDonald's elsewhere due to association of a bad experience. Eventually, this kind of discouragement of repeat customers may affect other franchisees or the overall corporation.

A solution to insure that the franchisee is adhering to the contractual terms of the franchise agreement is to closely monitor the franchise's activities through impromptu and routine visits. If the franchise fails to meet the 
standards, the franchisee should be forced to submit and implement a plan to bring the unit up to par pending further discipline from the corporate headquarters (including but not limited to fines and loss off privileges to use the corporate name).

Another potential problem with "free riding" deals with the amount of obligation that the franchiser (principal) feels toward the franchisee (agent) based on the amount of up-front cost and the royalty rate paid to the franchiser on a regular basis. Studies indicate that if franchisers are well compensated initially, they have no true incentive to monitor the franchisees against shirking since the corporation sees no real benefit in maintaining a high quality system. However, if they are moderately compensated initially with the intention of being compensated heavily thereafter, the franchiser is more likely to monitor each store closely. Defaulting on corporate obligations would lower the franchiser's return from establishing the franchise system since an unmonitored system would have greater franchisee "free riding" and lower sales. Furthermore, franchisees see the amount of the royalty rate in the franchise contract as a sign of the franchiser's devotion to develop and uphold the brand name/image of the franchise system therefore reassuring the potential franchisees (agents) that the franchise system (principal) is organized in a way to minimize agency problems. A probable solution is to require a modest investment up-front from the potential franchisee with the promise of a high royalty rate of return to the franchiser in the future. This solution should be effective in ensuring that both parties are serious about their commitment to upholding the policies within the company.

Another problem to consider is the moral hazard associated with the inability to transfer information in a non-hierarchical setting of business. If the franchiser (principal) has misinformation about the franchisee's (agent's) ability to perform certain tasks, the principal will have difficulty ensuring that the tasks are being performed correctly which in turn might encourage the franchisee to shirk on the proper performance of the task. In essence, if the franchisee realizes that there is a glitch in the monitoring system due to inability to check up on their performance, he may not be willing to put forth the amount of effort that is necessary to ensure adequate job performance. Conversely, if a franchisee (agent) is not able to get a message to the franchiser (principal) in a time of need, operations may halt or fail. For example, a franchisee may become frustrated when put on hold by the corporate office in an attempt to ask an important question concerning sales forecasting for the quarter. This inability to communicate would probably cause undue stress and a lack of confidence in support from the franchiser.

The solution to this problem is to establish a method of daily communication between the franchiser (principal) and the franchisee (agent) via email, log books, teleconferencing, to name a few. This system would allow information to be exchanged easily while eliminating the possibility of misinformation and simultaneously alleviating anxiety. It would be ridiculous to think that the aforementioned problems are the only issues faced in a franchise based relationship but they are a good illustration of the types of moral hazard and adverse selection that the franchisers and franchisees face in relation to Agency Theory.

\section{EXPLORING FRANCHISER-FRANCHISEE RELATIONSHIPS}

\section{Franchise Costs versus Owned Outlet Cost: Dual-Distribution Perspective}

The franchiser-franchisee relationship (FFR) can be examined from two theoretical perspectives, Agency Theory and Exchange Theory. There is a design model that illustrates several aspects of Agency Theory in a franchisee-franchiser relationship, such as the concept of franchising, the size and age of the chain, and the range of the contract that relate to control and autonomy. Agency Theory is relevant to a broad spectrum of issues pertaining to the contractual relationship between the franchisee and the franchiser. The contract protects the financial interests of both sides and sets criteria for operating the franchise or voiding the contract and nullifying the relationship. Agency Theory is more often applied to formal control and the optimization of the principle-agent organization. Agency Theory, however, does well to establish long-term relationships, but it lacks the flexibility to be equally applicable to short-term problems. Therefore, complexity of the franchise relationship is ignored.

Another theoretical perspective on franchising is through the application of the Exchange Theory, which is based on the interaction of people. The exchange relationships are maintained and formed when the relationship is 
attractive to both parties. Exchange transactions are more beneficial in the short term because of the dynamic and flexible nature of the interaction. In this respect autonomy must be addressed, due to its influence on the efficiency of the organization. Franchisees give up the formal authority, however, with that they must have autonomy, provided it does not have negative impact on the brand. Since the franchisee possesses the greatest amount of authority in the areas of purchasing and hiring, the application of Exchange Theory would be more beneficial in today's economy, due to its focus on the human element.

In a FFR, there are both internal and external tradeoffs involving Agency Theory. Some of these trade-offs include dual distribution, client risk sharing, taxation, internal agency costs and legal costs. Porter (1996) demonstrated conceptually how operational effectiveness is a necessary component to a company's success, but not the only component. In the past 20 years, management has been trying to increase the operational effectiveness of their companies. Management has been learning about total quality management, benchmarking, and reengineering tools. Applications of these tools are necessary when competition is not running an effective operation. Managers can use these tools to create best practices and place their company on the productivity curve. The strategy problem is that many managers are using these tools to increase their operational effectiveness, ignoring the need for a long-term solution. When these types of managers compete it "produces absolute improvement in operational effectiveness" ( $p$. 63), but it may also lead "to relative improvement for no one" (p. 63). Adding value through operational effectiveness without being strategic is not increasing profits.

Porter (1991, 1996, 1998, 1999a, 1999b, 2001) also argued that in order for a company to become a better competitor, the managers have to become effective strategic managers as well as effective operational managers. When managers are strategic, they "deliberately choose a different set of activities to deliver a unique mix of value" (Porter, 1996, p. 64). Delivering a unique product alone will not be enough to sustain a strategic position. So, strategic managers have evaluates all the activities of a firm. Then they will combine them in a unique system to deliver a unique product. As a company becomes more strategic, they become more competitive because their success would be hard to copy.

More managers do not generally evolve into strategic managers since few individuals want to take the responsibility of making the strategic decisions that have few measurable short-term benefits. Strategic management demands that the leadership makes decisions on what the company should do and what the company should not do. This type of decision-making is called making trade-offs and has much to do with Agency Theory's applications to FFR. One reason that operational effectiveness is the preferred way is that it has inherently little risks during the short term. Managers would be willing to make decisions if the risks were not so high on the long term. According to Porter (1996), managers are in need of "constant discipline and clear communication" (p. 77), but what managers really need is the courage to make decisions based on their intuition and their experienced analytical skills.

From an Agency Theory viewpoint, dual distribution can be analyzed in a cost versus cost trade-off schema. The approach argues that both franchising and company ownership have costs associated with them. Dual distribution is considered an internal solution to the cost tradeoff. Some of the costs in question are inefficiency of client risk sharing, franchisees that are free riding and the legal costs of terminating a franchise. Under dual distribution the mix of company ownership and franchising minimizes the sum of these total costs.

A dual-distribution franchise system is based on the option to expand simultaneously with a mix of company owned outlets and franchisee owned outlets. The company owned outlets have managers that act as agents for the owners. The franchisee outlets are based on performance incentives. The franchisee as the external agent is entitled to residual profits once the contract is fulfilled. There are franchisee payments that must be made to the franchiser in the form of an annual fee as well as a royalty on sales.

When looking at market demand and the impact strategic decisions may influence it several factors come into play, including point of sale service. The components are; the impact of outlet level services provided to the consumer enhancing value via the shopping experience, the franchiser's level of effort to streamline the supply chain to all retail outlets, which enhances the image and reputation of the brand with the customer. Managerial effort is often unverifiable and unobservable in their attempt to improved demand. 
The manager of an owned outlet has advantages that are not available to franchisees because they do not have annual franchisee fees and royalties to pay to the franchiser. Franchisees charge higher prices and provide a lower degree of customer service that helps compensate for the liability of fees and royalties to the franchiser. The dual distribution model of Agency Theory can be extended to include credible communication of franchise brand equity. This is necessary because the entire franchise system is based on several levels of trust between the franchiser and the franchisee. Therefore, the cost of opportunism is moved to the forefront of the franchising system. Included in franchise brand equity are all of those uncontrollable attributes that build customer value for each franchisee. In the long run brand equity is necessary in the decision making process for the franchisee. Hence, brand equity is an intangible asset, in that it is the customer's perception of brand value that is independent of the company's efforts to affect the customer viewpoint.

\section{STRATEGIC CONSIDERATIONS}

\section{Franchise Environment}

There are strategic considerations of a franchise that are both internal and external when looking at incentives and participation. The franchisee has specific incentives based on the contract written by the franchise. The contract has several elements, including an annual franchise fee and royalties on sales due to the franchiser. The internal and external agency tradeoffs directly affect growth rates and share of company outlets. When growth rates are low, internal agency conditions for seem prevalent. When profitability of franchise outlets increases growth rates then the external agency conditions are prevalent. Favorable conditions for external agency have the most impact reducing the company share the most.

\section{Strategic Issues}

Leavy (2003), discusses two strategic alternatives that are known as market position and core competence perspective and their differences to the other alternative that may have direct impact to the franchise environment. In the discussion of market position, Leavy mentioned how positioning is the work of Porter $(1991,1996)$ and gives the six principles of positioning, which include right goals, clear-value proposition, distinctive value chain, trade-offs, activity-chain alignment, and continuity of direction. Leavy discussed the importance of core competencies and more up-to-date versions of this perspective that were initially created jointly by Prahalad and Hamel (1994). Leavy suggested an idea that is central to core competencies, which include that "the relationship between core competence, core product and end product" (p. 31). Core competencies are essential in defining the strategic advantages associated with FFR. For example, Southwest Airlines is famous for its marketing position of its core competencies, while Canon is noted for its engineering and sales competencies. There are several issues related to the Agency Theory related to the FFR versus a company-owned store where a manager is hired to run its operations, based on its core competencies. For example purposes in this section of the paper, references will be limited to the FFR versus company-owned stores in the fast food industry, since fast food and business services account for more than 50\% of the international franchising of U.S. firms (Pizanti, 2003).

Agency Theory is based on several assumptions. First, it involves the separation of the owners of the store, the principals, and those who manage the operation of the store, the agent. The primary issue related to this point is that the owner's wishes may not be followed in the operation of the store. In the franchise arrangement, this is minimized because the franchiser grants the franchisee an ownership interest in the store. Thus, the franchisee becomes a stakeholder in the business. It will then be in the best interests of the franchisee to run the business in the best way possible. This will then benefit the franchiser. Should the franchisee not run the location in the way that the franchiser wishes, there are legal agreements that will back up the relationship and the franchisee may be subject to penalties. Initial capital investments are made by the franchisee. They could lose this investment by not running the franchise properly (which is in the best interests of the franchiser). The franchisee benefits from the ownership in the location by keeping almost all profits generated by his fast food franchise. The franchiser benefits from franchise fees (usually based on a percentage of gross profit) and revenue for supplying the items necessary for the fast food products sold by the franchise. Offering ownership allocation as compensation to the franchisee rather than fixed compensation solves two agency problems: adverse selection (the principal cannot completely verify the abilities and 
skills of the agent because the agent may misrepresent his abilities), and moral hazard (the principal cannot know if the agent is truly making and optimal investment of effort or is misdirecting his efforts to advance personal goals) (Pizanti 2003).

The franchisee also assumes the risks of hiring and training employees for the location. For the franchiser, allocation ownership also eliminates the cost of hiring, selecting, training and monitoring of new employees as it helps overcome managerial limits to new growth. The franchiser supplies the training material (at a cost) but does not assume the other risks involved with employees. The franchisee is then brought into an agency relationship with the employees that he hires. It is on a much smaller scale thus, is more manageable. By entering into a franchise agreement, the franchisee frees up more capital to expand into other areas that they do not currently operate in. This is valuable to the franchise as a whole because it brings growth and name recognition.

In the company-owned store model, the company hires a salaried manager to run the location. By not giving the manager any other additional incentive to run the fast food store in the best interests of the company (in other words, the most profitable way), the company risks that the store may not be as profitable as possible. The manager will only have the incentive to make sure the store is operating. There is no other incentive to operate the store efficiently to ensure maximum profitability. The company does receive all the profit that fast food location will bear. But this comes with greater risks. The company must invest its own capital and take on the responsibility of hiring and training employees to run the location.

Another issue related to Agency Theory involves delegation of decision-making authority by owners to managers. In both of the arrangements above, strategic decision making stays with the company. The difference is how the decision-making is done at the local (store) level. In the franchise arrangement, decision making for the particular franchised location is in the franchisee's hands. The franchisee, through the ownership position taken to acquire the franchise, will run the location in the best way profitable to achieve maximum profitability. This benefits the company in franchise fees received (which are usually based on a percentage of gross profit) and through the sale of supplies to the location. In the company-owned store set up, the local decision making process is in the hands of a salaried manager hired by the company to run the fast food outlet. The company hopes that the manager runs the location in order to achieve maximum profitability but the salaried manager, unlike the franchisee, has no real vested interest in achieving maximum profitability or best usage of company resources.

Moral hazard issues, while minimized in the franchise relationship, can occur in the franchise relationship and the company-owned store set up. In the franchiser-franchisee relationship, moral hazard can occur when the franchisee does not provide the franchiser with accurate information related to sales and profit. Since most franchise fees are based on a percentage of gross profit, there is the probability that the franchiser may not receive all fees it is entitled to if the franchisee manipulates the sale figures. Other moral hazard issues such as the company not being able to monitor every decision and franchisees operating only to pursue their best interests are minimized, since the franchise agreement has given the franchisee an ownership interest. This ties the interests of the franchisee with those of the franchiser. Moral hazard is sues are magnified in a company-owned store arrangement in that the salaried managers have no real interest (other than keeping their current positions) in operating their locations in the best way possible that would benefit the company. Salaried managers' decisions may not be in the best interests of the company but rather in the best interests of the particular manager making the decision. If there were a tough decision for a salaried manager to make that would in one way affect the locations long-term profitability and his/her employment, the salaried manager would almost always make the decision that does not affect the salaried manager's employment position in a negative way. This may not always be inline with the best interests of the company. This is a potential agency problem where the managers act to protect their status. In this case, their status is the status of their employment.

\section{GENERAL CONCLUSIONS AND IMPLICATIONS}

When coming up with conclusions and recommendations for the franchiser-franchisee relationship versus the company-owned store setup for a fast food company, there is a need to consider the solutions to the agency problem. The following concepts and recommendations are based on a structure suggested by Pearce and Robinson, 20030. 
- Define the agent's responsibilities in a contract, including elements like bonuses to align managers and companies' interests.

The franchise arrangement, which specifies the responsibilities and compensation plan for the franchisee must be spelled out in the franchise contract. In a typical company-owned store arrangement, many companies have a portion of the salaried manager's compensation tied to location-related performance bonuses. They also give managers stock in the corporation in the form of employee stock purchase plans and $401(\mathrm{k})$ retirement plans. This gives the salaried managers an ownership position in the company tying their compensation to the performance of the company as a whole.

- $\quad$ Pay managers a premium for their services.

In terms of the franchise arrangement, the franchisee's compensation is usually directly tied to the performance of the franchise location. In terms of a company-owned store, most fast food manager's compensation does not exceed $\$ 40 \mathrm{~K}$ a year. This does not seem to really be a premium-pay arrangement.

- $\quad$ Structure a back loaded compensation plan for managers.

The establishment of the franchise arrangement, the franchisee typically does not receive compensation unless the location is profitable. In terms of a company-owned store, the most typical method for such salaried managers to receive a back loaded compensation is through the employee stock purchase plans and stock in the company-provided 401(k) plan.

- $\quad$ Create teams of managers across different company locations to focus on overall company performance.

Focusing on a franchise arrangement, most franchisees' have groups that bring franchisee issues to the company's attention. For example, in McDonald's case, the franchisees were able to get rid of unprofitable products such McLean and the Arch Deluxe through these organizations. These products affected the franchisees' profitability and their organization was able to convince McDonald's to eliminate them. Company-owned stores, on the other hand, many companies have focus groups made up of salaried managers. These groups do not exercise the power and influence of the franchisee groups mentioned above.

Our recommendation is to go with the dual distribution franchise systems, which are distinguished by the option available to expand simultaneously with a mix of company owned outlets and franchisee owned outlets (Seshadri 2002). For example, McDonald's operates successfully in the U.S. under this model, although its return on equity (ROE) has been traditionally poor. Approximately $80 \%$ of locations are franchisee owned while approximately $20 \%$ are company-owned and operated locations. This arrangement allows a fast food franchise to expand through the franchise locations (while limiting the amount of capital being invested) and benefiting from the company-owned stores, which would be more manageable (thus being able to somewhat lessen the amount of agency problems due to less company-owned locations). This model has worked successfully for franchiser-franchisee relationships, such as McDonald's since its founding in 1955. There are numerous market trends and undercurrents that are promoting change in such a setup, such as been more culturally sensitive, that are directly affecting the future of the franchise industry, but there are many success stories that illustrate that there many viable models.

\section{REFERENCES}

1. Brickley, J.A., Dark, F.H., and Weisbach, M.S. (1991, spring). An agency perspective on franchising. Financial Management, 20(1): 27-38.

2. Castrogiovanni, G.J, Bennett, N., and Combs, J.G. (1995, January). Franchisor types: reexamination and clarification. Journal of Business Management, 33(12): 45-53.

3. Combs, J.G. and Castrogiovanni, G.L. (1994, April). Franchiser strategy: a proposal model \& empirical test of franchise vs. company ownership. Journal of Business Management, 32(2): 37-49. 
4. Combs, J.G., Michael, S.C., and Castrogiovanni, G.L. (2004). Franchising: a review and avenues to greater theoretical diversity. Journal of Management, 30(6): 907-1003.

5. Hamel, G. and Prahalad, C.K. (1994, September 5). Seeing the future first. Fortune, p. 64-70.

6. Leavy, B. (2003). Assessing your strategic alternatives from both a market position and core competence perspective. Strategy \& Leadership, 31(6): 29-41.

7. Mathieu, J., (1997). Agency Theory Framework. www.babson.edu. [Online]. Available:

(http://www.babson.edu/entrep/fer/papers96/shane/shane3.htm).

8. Pizanti, I. and Lerner, M., Examining control and autonomy in the franchiser-franchisee relationship, International Small Business Journal, (2003)

9. Pearce, J.A. and Robinson, B.R.(2003). Strategic Management: Formulation, Implementation and Control, $8^{\text {th }}$ Ed. McGraw-Hill: New York.

10. Porter, M.E. (1991). Towards a dynamic theory of strategy. Strategic Management Journal, 12: 95-117.

11. Porter, M.E. (1996). What is strategy? Harvard Business Review, 74(6): 61-78. (November/December).

12. Porter, M.E. (1998). Clusters and the new economics of competition. Harvard Business Review, 76(6): 7790.

13. Porter, M.E. (1999a). Michael Porter on competition. Antitrust Bulletin, 44(4): 841-880. (Winter).

14. Porter, M.E. (1999b). Creating advantage. Executive Excellence, 16(11): 13-14.

15. Porter, M.E. (2001). Strategy and the Internet. Harvard Business Review, 79(3): 62-78.

16. Seshadri, S. (2002, September). Outlet ownership in franchising systems: an agency based approach. Managerial and Decision Economics, 23(6): 355-368. 